\title{
Short Communication: \\ Using ecological parameters to assess the sustainability of mangrove ecotourism in Jeneponto, South Sulawesi, Indonesia
}

\author{
HARDIANTY ASKAR ${ }^{1}$, HAMZAH TAHANG ${ }^{2}$, SUTINAH SUTINAH ${ }^{2}$, SITTI FAKHRIYYAH ${ }^{2}$, \\ AHMAD BAHAR ${ }^{3}$, JOEHARNANI TRESNATI $^{3}$, AMBO TUWO $^{4,5, *}$ \\ 'Graduate Program of Fisheries Science, Department of Fisheries, Faculty of Marine Sciences and Fisheries, Universitas Hasanuddin. Jl. Perintis \\ Kemerdekaan Km. 10, Tamalanrea, Makassar 90245, South Sulawesi, Indonesia \\ ${ }^{2}$ Program of Fisheries Socio-Economic, Department of Fisheries, Faculty of Marine Sciences and Fisheries, Universitas Hasanuddin. Jl. Perintis \\ Kemerdekaan Km. 10, Tamalanrea, Makassar 90245, South Sulawesi, Indonesia \\ ${ }^{3}$ Program of Aquatic Resources Management, Department of Fisheries, Faculty of Marine Sciences and Fisheries, Universitas Hasanuddin. Jl. Perintis \\ Kemerdekaan Km. 10, Tamalanrea, Makassar 90245, South Sulawesi, Indonesia \\ ${ }^{4}$ Program of Marine Science, Department of Marine Science, Faculty of Marine Sciences and Fisheries, Universitas Hasanuddin. Jl. Perintis \\ Kemerdekaan Km. 10, Tamalanrea, Makassar 90245, South Sulawesi, Indonesia. Tel.: +62-411-586025, `email: ambotuwo62@ gmail.com. \\ ${ }^{5}$ Multitrophic Research Group, Faculty of Marine Sciences and Fisheries, Universitas Hasanuddin. Jl. Perintis Kemerdekaan Km. 10, Tamalanrea, \\ Makassar 90245, South Sulawesi, Indonesia
}

Manuscript received: 22 April 2021. Revision accepted: 30 July 2021

\begin{abstract}
Askar H, Tahang H, Sutinah S, Fakhriyyah S, Bahar A, Tresnati J, Tuwo A. 2021. Short Communication: Using ecological parameters to assess the sustainability of mangrove ecotourism in Jeneponto, South Sulawesi, Indonesia. Biodiversitas 22: $3571-3577$. Mangrove forest is an essential ecosystem that provides various ecosystem services. Among various land use management in mangrove areas, ecotourism is considered as a sustainable economic activity that can improve socio-economic benefits while conserving the mangrove ecosystem. Therefore, ecotourism management must refer to sustainable development principles. This study aims to assess the sustainability status of mangrove forests in Idaman Mangrove Ecotourism in Balang Baru Village, Tarowang Sub-district, Jeneponto District, South Sulawesi, Indonesia using some parameters including the extent, density and diversity of mangrove vegetation, tidal height and animal biota that occurred in the mangroves. The study used line transect method and quadrat transect, and the data were analyzed using Rapfish (Rapid Appraisal for Fisheries) method. The study indicated that the sustainability status of IME for the ecological dimension was in the entirely sustainable category with an ecological dimension value was 58.50. While the mangrove is currently managed sustainably, to go further, it requires all stakeholders' cooperation in improving the dimensions of sustainability, which had a low value, especially the mangrove trees thickness.
\end{abstract}

Keywords: Biodiversity, ecotourism, environmental services, mangrove, sustainability

\section{INTRODUCTION}

Coastal zone is transitional area between terrestrial and marine ecosystems that have enormous natural resources and environmental services. One of the transitional ecosystems in the coastal zone is mangrove ecosystem (Tresnati et al. 2020). The mangrove ecosystem is an ecotone that terrestrial, freshwater, and seawater habitats meet in one site, creating an ecosystem with many unique characteristics. As such, mangrove forest has high biodiversity due to the various species of plant and animals which can survive in the three types of habitats. Mangrove forest is also a support system for the surrounding coastal ecosystems, such as coral reefs and seagrass beds (Honda 2013).

In general, the natural resources contained in mangrove ecosystems are renewable (Fahrian et al. 2015). One of the resources in mangrove ecosystem is mostly in the form of biodiversity in which the higher the biodiversity, the greater the capacity for resistance and resilience, and the greater the carrying capacity of the mangrove habitat in providing ecosystem services (Tuwo 2011). If managed sustainably, mangrove ecosystem can improve the community's welfare, conversely if mangrove is disturbed and degraded it will take a long time to recover (Tahang et al. 2019).

Sustainable mangrove forest management is very urgent because many mangrove forests throughout the world have been severely damaged. Of the 16.53 million hectares of mangrove ecosystems in the world, the area of mangrove forests has decreased by $20 \%$ in 20 years (Asihing 2014). The rate of mangrove forest loss is faster in developing countries, where more than $90 \%$ of the world's mangrove forests are located (Carter et al. 2015). For example, Indonesia has the most extensive mangrove forests globally with the highest biodiversity contained in their mangrove ecosystems. In 2015, Indonesia had 3.24 million hectares of mangrove forests, yet only $30.7 \%$ of such mangroves were in good condition, $27.4 \%$ were moderately degraded, and $41.9 \%$ were severely degraded or deforested (Kusmana 2017). While there are some efforts to rehabilitate the degraded mangrove forest, the rate of mangrove 
deforestation and degradation outpaces the rate of rehabilitation.

One way of the sustainable management of mangrove ecosystem is ecotourism. Ecotourism is a concept of utilizing environmental services in an integrated way that is oriented towards environmental conservation (Thompson et al. 2018). Mangrove ecotourism is designed to preserve and protect mangrove ecosystems that prioritize aspects of naturalness, uniqueness, and authenticity of natural resources management (Gigović et al. 2016).

South Sulawesi is one of the original habitats of mangrove forests in Indonesia. The mangrove forests in South Sulawesi have decreased rapidly due to the conversion into brackish water ponds, housing, and industrial areas. In 1950, South Sulawesi had mangrove forests covering an area of 112,000 hectares. In 40 years, the mangrove forests in South Sulawesi decreased to 39,000 hectares, decreasing by $65 \%$. In order to slow down such deforestation, ecotourism is then promoted as an alternative for the sustainable use of mangrove forests in South Sulawesi (Tresnati et al. 2020).

One of the mangrove ecotourism locations in South Sulawesi is Idaman Mangrove Ecotourism (IME) located in Jeneponto District. Mangrove ecotourism in this area has been developed by combining the objectives of education, research, conservation, and improvement of coastal community welfare (Basyuni et al. 2018). Since its establishment in 2018, IME has never been monitored to assess its sustainability dimension. Therefore, monitoring activities to assess the ecological status of the mangrove in the area must be conducted. This study aims to assess the ecological status of mangrove forest in Idaman Mangrove Ecotourism using some parameters including the extent, density, and diversity of mangrove vegetation, tidal height, and animal biota that occurred in the mangroves. We expect the results of this study can serve as baseline information for future monitoring and evaluation to provide insight on the sustainability of mangrove ecosystem in Idaman Mangrove Ecotourism.

\section{MATERIALS AND METHODS}

\section{Study period and area}

The study was done from June to August 2020 at Idaman Mangrove Ecotourism in Balang Baru Village, Tarowang Sub-district, Jeneponto District, South Sulawesi, Indonesia (Figure 1). The mangrove area in IME covers an area of $117 \mathrm{Ha}$ and is located between $\mathrm{S} 5^{\circ} 23^{\prime} 12^{\prime \prime}-\mathrm{S}$ 5०42'1.2" and E 119²9'12" - E 11956'44.9".

Initially, the mangrove area in IME was a natural mangrove forest with an extent of 62.5 hectares used by local communities as a source of firewood. After the Maumere Tsunami occurred in 1992 and the tidal wave reached Balang Baru Village, the local community felt that the greater benefits of the natural mangrove area were greater if it was being conserved. At that time, the Maumere Tsunami did not cause any significant damage because the tsunami waves were blocked by the mangrove vegetation that grew along the coast of Balang Baru Village.

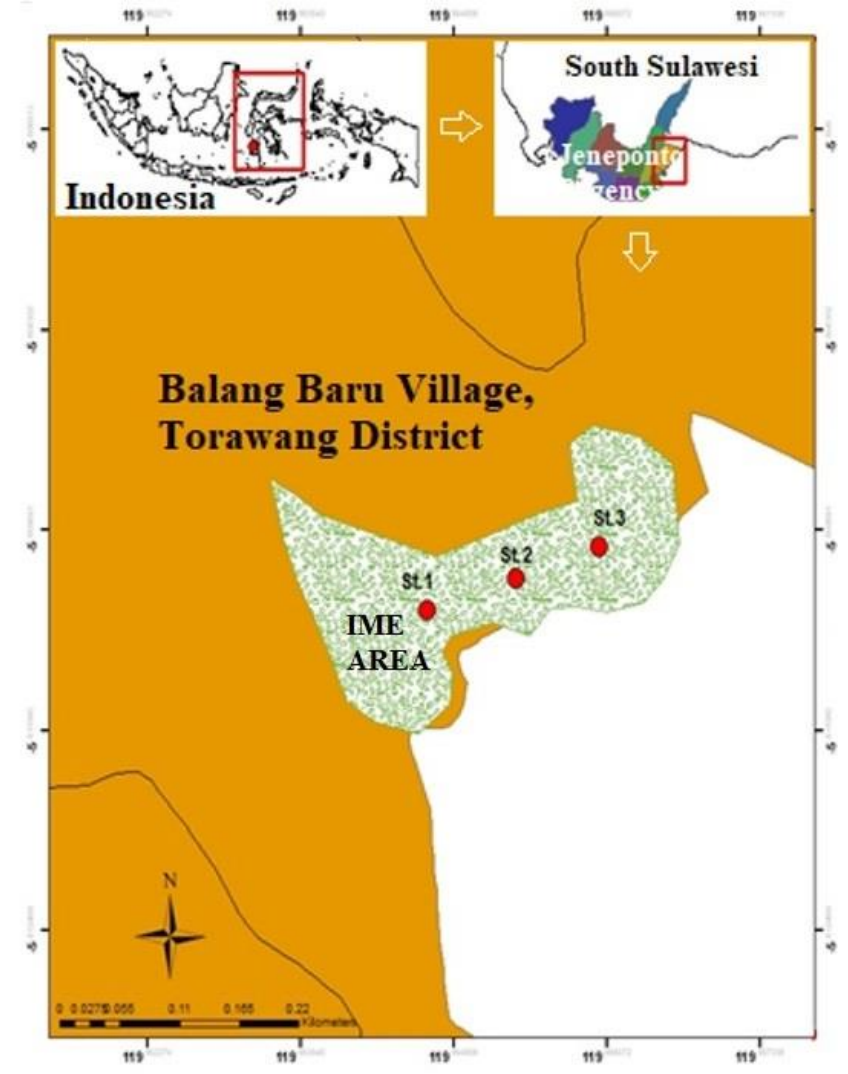

Figure 1. Map of the study area in Idaman Mangrove Ecotourism (IME) in Balang Baru Village, Tarowang Sub-district, Jeneponto District, South Sulawesi, Indonesia

Since then, the local community of Balang Baru Village has realized the benefits of mangrove forests as beach protectors and has started planting mangroves. To increase the economic benefits of mangrove forests in Balang Baru Village, the government assists in developing mangrove ecotourism in the form of building tracks, gazebos, halls, and selfie points. The District Head (Bupati) of Jeneponto officially opened IME in December 2018. The tourism working group was formed involving local communities to operate the IME. For ecotourism facilities' operational and maintenance costs, the IME management collects fee for each visitor of Rp. 3,000 per person.

Mangrove vegetation in IME is dominated by Rhizophora apiculata, Rhizophora mucronata, and Avicennia marina (Figure 2). Mangrove vegetation in IME grows thickly from the sea to the mainland. Rhizophora apiculata and Rhizophora mucronata grow in the outer zone and directly adjacent to the sea, while Avicennia marina grows in the inner area and is directly adjacent to the beach or land area.

\section{Data collection procedure}

The observations of ecological parameters were done in the IME area using the line transect method, which was placed perpendicular to the coastline, and stretched from the sea to the land area (Tuwo 2011). Sampling was done at three stations using the quadrant transect measuring $10 \mathrm{x}$ $10 \mathrm{~m}^{2}$ as an observation area (Sofian et al. 2012). 
Parameters measured were mangrove thickness (m) mangrove density (trees per $100 \mathrm{~m}^{2}$ ), mangrove species, tides (m), and biota as ecotourism objects. Mangrove thickness was the width of mangrove tree cover or canopy cover. The mangrove thickness was measured perpendicularly from the outermost mangrove tree bordering the sea area to the last mangrove tree bordering the land area. Mangrove thickness was calculated using field observations and satellite image analysis (Mursalim et al. 2020).

\section{Data analysis}

The suitability index of mangrove ecotourism was analyzed using a quality measure or standard of mangrove resources as the ecotourism object by using the equation:

$$
S I=\sum_{i=1}^{n}(B i x S i)
$$

Where: $\mathrm{n}$ was the number of suitability parameters, $\mathrm{Bi}$ was the value to-i, $\mathrm{Si}$ was the parameter value to-i (Yulianda 2019). The suitability level was determined using mangrove ecotourism's suitability value (Yulianda 2019) (Table 1).

The tourism suitability calculation was done based on the multiplication of the index and score for each parameter. The calculation results were then categorized using four classes of suitability, namely: SI $\geq 2.5$ for the very suitable category, $2.0 \leq \mathrm{SI}<2.5$ for suitable, $1 \leq \mathrm{SI}<$ 2.0 for less suitable, and IKW $<1$ for not suitable.
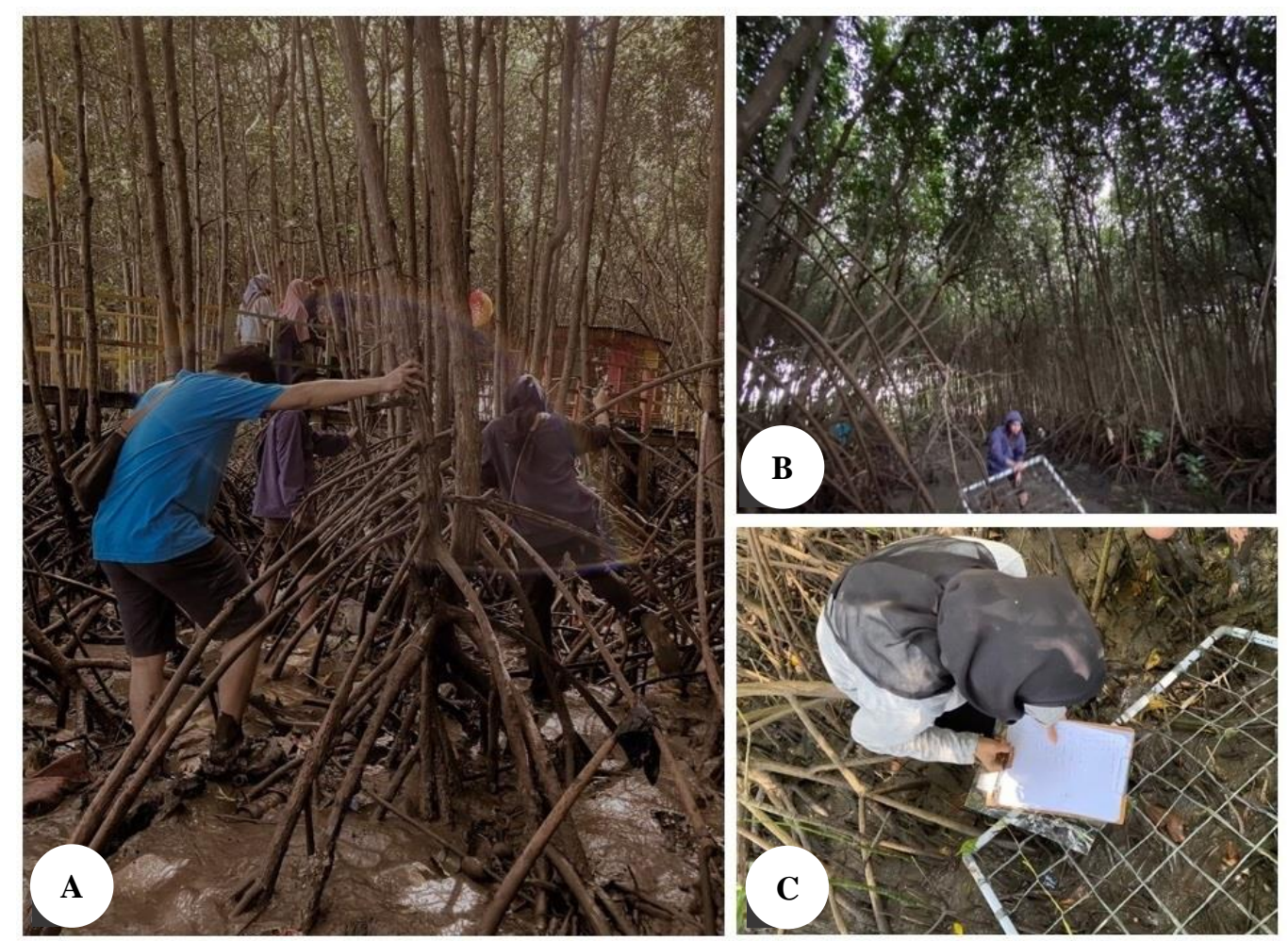

Figure 2. The mangrove trees condition (A), and the sampling activities (B-C) at the Idaman Mangrove Ecotourism (IME) area at Balang Baru Village, Tarowang Sub-district, Jeneponto District, South Sulawesi, Indonesia

Table 1. The value of index and score used to assess mangrove ecotourism suitability in the Idaman Mangrove Ecotourism, Balang Baru Village, Tarowang Sub-district, Jeneponto District, South Sulawesi, Indonesia

\begin{tabular}{|c|c|c|c|c|c|c|c|c|c|}
\hline Parameters & Index & Very suitable & Score & Suitable & Score & Less suitable & Score & Not suitable & Score \\
\hline $\begin{array}{l}\text { Mangrove } \\
\text { thickness (m) }\end{array}$ & 0.38 & $>500$ & 3 & $>200-500$ & 2 & $50-200$ & 1 & $<50$ & 0 \\
\hline $\begin{array}{l}\text { Mangrove density } \\
\left(\text { trees per } 100 \mathrm{~m}^{2} \text { ) }\right.\end{array}$ & 0.25 & $>15-20$ & 3 & $>10-5 ;>20$ & 2 & $5-10$ & 1 & $<5$ & 0 \\
\hline $\begin{array}{l}\text { Mangrove species } \\
\text { number }\end{array}$ & 0.15 & $>5$ & 3 & $3-5$ & 2 & $1-2$ & 1 & 0 & 0 \\
\hline Tidal height (m) & 0.12 & $0-1$ & 3 & $3-4$ & 2 & $>2-5$ & 1 & $>5$ & 0 \\
\hline $\begin{array}{l}\text { Ecotourism object } \\
\text { biota }\end{array}$ & 0.10 & $\begin{array}{l}\text { Fish, shrimp, } \\
\text { crab, mollusks, } \\
\text { reptiles, birds }\end{array}$ & 3 & $\begin{array}{l}\text { Fish, shrimp, } \\
\text { crab, } \\
\text { mollusks }\end{array}$ & 2 & $\begin{array}{l}\text { Fish, } \\
\text { mollusks }\end{array}$ & 1 & $\begin{array}{l}\text { One of the } \\
\text { object biotas }\end{array}$ & 0 \\
\hline
\end{tabular}


Table 2. Ecological parameters, suitability index value, and status of suitability index of the Idaman Mangrove Ecotourism, Balang Baru Village, Tarowang Sub-district, Jeneponto District, South Sulawesi, Indonesia

\begin{tabular}{|c|c|c|c|c|c|c|c|}
\hline \multirow{2}{*}{ Parameter } & \multicolumn{3}{|c|}{$\begin{array}{l}\text { Station scores } \\
\end{array}$} & \multirow{2}{*}{ Coefficients $(\mathrm{C})$} & \multicolumn{3}{|c|}{ Suitability Index Value } \\
\hline & Station 1 & Station 2 & Station 3 & & Station 1 & Station 2 & Station 3 \\
\hline Mangroves thickness & 1 & 2 & 2 & 0.380 & 0.380 & 0.760 & 0.760 \\
\hline Mangrove density & 3 & 3 & 3 & 0.250 & 0.750 & 0.750 & 0.750 \\
\hline Mangrove species & 1 & 1 & 1 & 0.150 & 0.150 & 0.150 & 0.150 \\
\hline Tidal & 2 & 2 & 2 & 0.120 & 0.240 & 0.240 & 0.240 \\
\hline Ecotourism object biota & 3 & 3 & 3 & 0.100 & 0.300 & 0.300 & 0.300 \\
\hline Total suitability index value & & & & & 1.820 & 2.200 & 2.200 \\
\hline Suitability status & & & & & Less suitable & Suitable & Suitable \\
\hline
\end{tabular}

Sustainability was analyzed using the Rapid Appraisal for Fisheries (Rapfish). Rapfish was based on the ordination technique using the Multi-dimensional Scaling (MDS) technique (Kavanagh and Pitcher 2004). MDS analysis aimed to transform information or data about similarities or preferences described in multi-dimensions (Schaduw 2018). The MDS ordinance of the attributes' leverage factor dimensions was based on the Root Mean Square (RMS) on the x-axis (Kholil et al. 2015).

The aspects used were ecological attributes. There were six ecological attributes, i.e., the five attributes that have been described in Table 1, another attribute was the suitability index (SI) of the mangrove ecotourism area. SI score was determined based on the SI value, i.e., a score of 3 if SI $\geq 2.5$; a score of 2 if $2.0 \leq \mathrm{SI}<2.5$; a score of 1 if $1.0 \leq \mathrm{SI}<2.0$; and a score of 0 if SI $<1.0$ (Yulianda 2019).

\section{RESULTS AND DISCUSSION}

\section{Results}

The results of sustainability status of the mangrove ecosystem at the Idaman Mangrove Ecotourism were as follows: (i) the mangroves thickness ranged from 127 to $209 \mathrm{~m}(179.67 \pm 45.71)$, resulting in a score of one; (ii) the mangrove density was $16-22$ trees per $100 \mathrm{~m}^{2}(19 \pm 3)$, with a score of three; (iii) the mangrove species found were Rhizophora apiculata, $R$. mucronata, and Avicennia marina (Figure 3.A-C), resulting in a score of two; (iv) the mean tidal range was $1.81 \mathrm{~m}$, with a score of two; (v) The fauna found were birds, bats, reptiles, fish, crabs, and mollusks (Figure 3.D-I), with a score of three; and (vi) the suitability index of mangrove tourism area was 1.82-2.35 $(2.12 \pm 0.27)$, with a score of two (Table 2$)$.

The six ecological parameters to assess sustainability indicated that mangrove ecotourism's index value was 58.50 (Figure 4.A). The stress value was $15.01 \%$, with a confidence interval value of $94.41 \%$, which means it has met the fit category's goodness. The ecological dimension leverage analysis indicated that the six ecological attributes had no value that exceeds eight, so no ecological dimension attribute was dominant in influencing the mangrove ecosystem sustainability. The ecological attribute values were 1.46-6.30 (Figure 4.B).
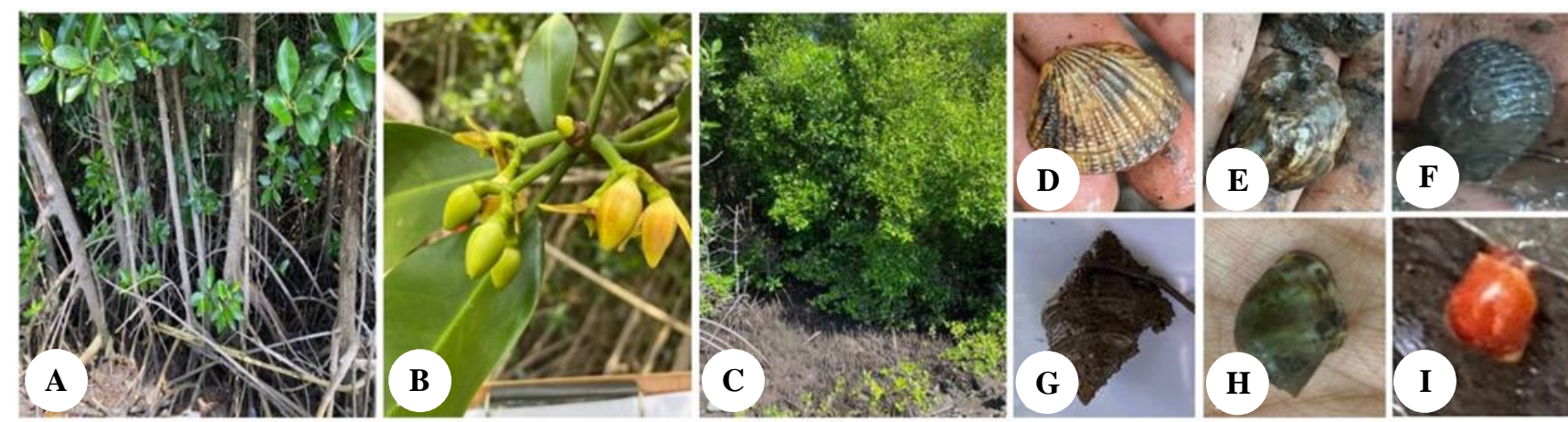

Figure 3. Mangrove species and benthic organisms found at the Ideal Mangrove Ecotourism (IME) in Balang Baru Village, Tarowang Sub-district, Jeneponto District, South Sulawesi, Indonesia. A. Rhizophora apiculata, B. Rhizophora mucronata, C. Avicennia marina, D. Anadara sp., E. Crassostrea gigas, F. Nerita articulata, G. Indothais gradata, H. Cassidula aurisfelis, I. Sphaerassiminea miniata 


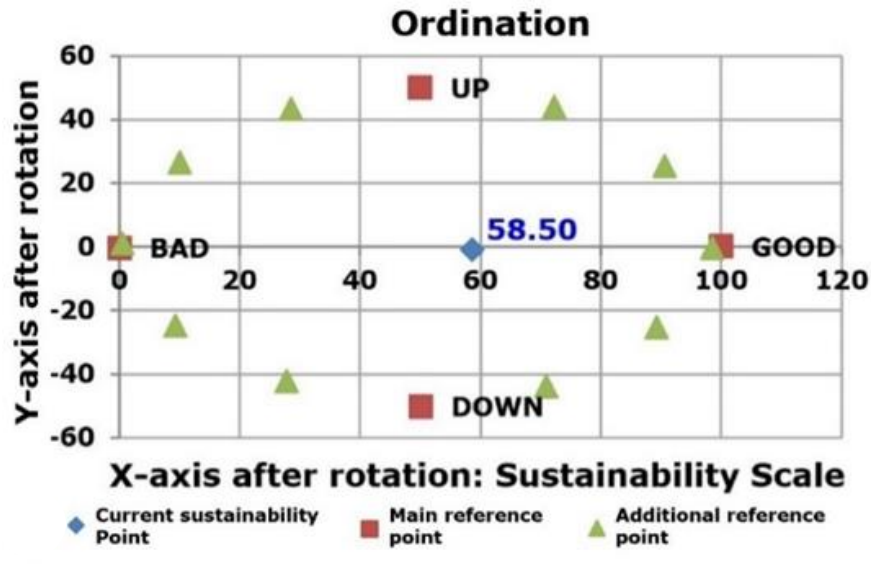

A

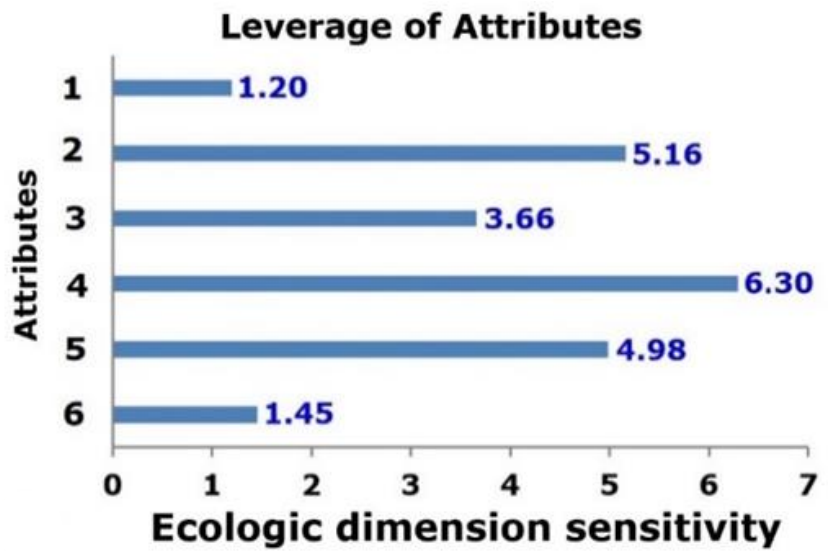

B

Figure 3. Sustainability status (A) and ecological dimensions sensitivity (B) of Idaman Mangrove Ecotourism in Balang Baru Village, Tarowang Sub-district, Jeneponto District, South Sulawesi, Indonesia. 1: tourism suitability index, 2: attractions, 3: tides, 4: mangrove species, 5: mangrove density, and 6: mangrove thickness.

\section{Discussion}

Mangrove ecotourism is an alternative to sustainable management in mangrove ecosystems that can provide economic benefits and preserve the ecological functions of mangrove forests. Ecologically, mangrove forests are natural habitats where fish species and high economic value organisms lay eggs, shelter, and forage, especially in the larval and juvenile stages or in the early stages of the life cycle (Vaslet et al. 2012). Ecologically, mangrove forests also function as a supporting ecosystem for other coastal ecosystems, such as seagrass and coral reef ecosystems (Ramirez-Martínez et al. 2016). Mangrove ecosystems produce organic matter, detritus, and nutrients distributed naturally to the seagrass ecosystem and surrounding coral reefs (Tuwo and Tresnati 2020). Naturally, the more fertile the mangrove ecosystem, the healthier the seagrass and coral ecosystems around it. Therefore, degradation of mangrove forests will harm coastal fisheries, such as a decrease in fish and shrimp catches and a shift in the base of the food chain from detritus feeder to plankton feeder, which can drastically reduce the productivity of mangrove forests and their surrounding ecosystems. The degradation of mangrove forests has a major impact on coastal fisheries, such as decreased fish and shrimp catches (Tresnati and Tuwo 2020).

Another benefit of mangrove forests, if they are conserved, is that they function as protection from storms, tsunami hazards, floods, and erosion. The 2004 Aceh and Nias Tsunami demonstrated the importance of mangrove forests for coastal protection; after the tsunami, the area covered by mangrove vegetation was relatively safe and less affected by the tsunami. Naturally, the mangrove ecosystem also functions as a sediment trap, recyclers of nutrients, and reduces seawater intrusion (Tresnati and Tuwo 2020).

Mangrove ecotourism is a fast-growing trend of sustainable development in natural mangrove forest areas (Sari et al. 2020) and rehabilitated mangrove forests in
Indonesia (Massiseng et al. 2020, Mursalim et al. 2020). Mangrove ecotourism is an economic activity that can significantly improve the preservation of mangrove forests and increase the socio-economic welfare of communities around the mangrove forests. The economic value of mangrove forests is estimated USD 3,624.98 to USD 26,734.61 per ha per year (Marlianingrum et al. 2019).

The ecological dimension is an essential factor in assessing ecotourism sustainability because it reflects the good or bad conditions of the environment and mangrove forest resources (Handayani et al. 2020). The six attributes used in this study were the results of a literature review that indicated that these six attributes were the valid attributes to assess mangrove ecotourism's sustainability. Mangrove thickness attribute was essential to consider in ecotourism activities because mangrove trees function as a breaker of wave energy that can cause coastal abrasion (Sawitri et al. 2013). The mangroves thickness in the IME was thinner than the mangrove ecotourism areas in the surrounding islands, which were more challenging to reach by people who often use mangrove forest resources uncontrollably.

The mangrove density attribute represents the mangrove forest productivity (Noor and Ully 2018) and each mangrove species' ability to cope with very dynamic environmental conditions (Balke et al. 2013). The three mangrove species found in IME are pioneer species in mangrove forest succession. The muddy substrate conditions supported the tree mangrove species' thickness and density (i.e., $R$. mucronata, $R$. apiculata, A. marina) in the IME area. The muddy substrate is very good for the mangrove development of $R$. mucronata and A. marina (Mughofar et al. 2018).

The mangrove ecosystem in the IME area had a high level of fauna biodiversity. This fauna indicated that ecologically, this ecosystem had fairly good ecosystem stability, approaching a relatively natural mangrove ecosystem (Sari et al. 2020). Some interesting fauna species used as tourist objects in the IME area were birds, bats, reptiles, fish, crabs, and mollusks. 
The presence of aquatic, land and air fauna in the IME area illustrates that mangrove ecotourism is an alternative model of mangrove ecosystem utilization expected to provide economic and ecological benefits simultaneously without disturbing the balance of the mangrove ecosystem (Tuwo 2011). This biodiversity will continue to increase over time. In mangrove ecotourism areas developed earlier, such as Tongke-Tongke mangrove ecotourism, the number of macrozoobenthic species found was 45, consisting of 27 detritivorous, 8 filter feeders, 6 predators, and 4 scavengers (Tuwo 1997).

IME was entirely sustainable because it had a good fit (Suwarno et al. 2011), low-stress value, and a high determination coefficient. Leverage analysis aims to determine which attributes were sensitive to the sustainability index. There were no dominant attributes affecting ecotourism management's sustainability from an ecological aspect in the ecological dimension. Even though the sustainability index's value was categorized as entirely sustainable, the sustainability aspect still needs to be improved so that the IME management becomes optimal. If the ecological attribute was in the $2-6 \%$ range, this indicates no dominant factor. If the factor value $<2$, then this indicates that the factor did not affect. Meanwhile, if the factor value $>8$, this indicates that the factor concerned was the dominant factor (Kavanagh and Pitcher 2004).

In conclusion, the results of this study demonstrated that the Idaman Mangrove Ecotourism had a sustainable status assessed from six ecological parameters. The sustainability index of the ideal mangrove ecotourism management determines how sustainable the IME can go. How far the IME management can go is determined by the score on the sustainability index diagram. The farther from the zero and the more balanced the three dimensions score, the higher the sustainability level of IME management and the farther IME management can go. A synergistic partnership between all stakeholders is required to improve sustainability especially the mangrove trees thickness.

\section{ACKNOWLEDGEMENTS}

We thank to the management of the Idaman Ecotourism Mangrove, Jeneponto, Indonesia. Thanks are also conveyed to all stakeholders for the warm cooperation during this field study.

\section{REFERENCES}

Asihing K. 2014. Actor, interest and conflict in sustainable mangrove forest management - a case from Indonesia. Intl J Mar Sci 4 (16): 150-159. DOI: $10.5376 /$ ijms.2014.04.0016

Balke T, Webb EL, van den Elzen E, Galli D, Herman PM, Bouma TJ. 2013. Seedling establishment in a dynamic sedimentary environment: a conceptual framework using mangroves. J Appl Ecol 50 (3): 740 747. DOI: $10.1111 / 1365-2664.12067$

Basyuni M, Bimantara Y, Siagian M, Wati R, Slamet B, Sulistiyono N, Nuryawan A, Leidonad R. 2018. Developing community-based mangrove management through eco-tourism in North Sumatra, Indonesia. IOP Conf Ser: Earth Environ Sci 126: 012109. DOI: $10.1088 / 1755-1315 / 126 / 1 / 012109$.
Carter HN, Schmidt SW, Hirons AC. 2015. An international assessment of mangrove management: incorporation in integrated coastal zone management. Diversity 7 (2): 74-104. DOI: 10.3390/d7020074.

Fahrian H, Hilman H, Putro SP, Muhammad F. 2015. The potential for ecotourism in the mangrove area, Mororejo Village, Kendal Regency. Biosaintifika: J Biol Biol Edu 7 (2): 105-111. [Indonesian]

Gigović L, Pamučar D, Lukić D, Marković S. 2016. GIS-Fuzzy DEMATEL MCDA model for the evaluation of the sites for ecotourism development: A case study of "Dunavski ključ" region, Serbia. Land Use Policy 58: 348-365. DOI: 10.1016/j.landusepol.2016.07.030

Handayani S, Bengen DG, Nurjaya IW, Adrianto L, Wardiatno Y. 2020. The sustainability status of mangrove ecosystem management in the rehabilitation area of Sayung Coastal Zone, Demak Regency, Central Java Indonesia. AACL Bioflux 13 (2): 865-884.

Honda K, Nakamura Y, Nakaoka M, Uy WH, Fortes MD. 2013. Habitat use by fishes in coral reefs, seagrass beds and mangrove habitats in the Philippines. PLoS One 8 (8): e65735. DOI: 10.1371/journal.pone.0065735.

Kavanagh P, Pitcher TJ. 2004. Implementing Microsoft Excel Software for Rapfish: A technique for the rapid appraisal of fisheries status. Fisheries Centre Research Reports. University of British Columbia, Vancouver, Canada.

Kholil K, Dharoko TA, Widayati A. 2015. Multidimensional scaling approach for sustainability evaluation of Cirata Reservoir - West Java Province. Jurnal Manusia dan Lingkungan 22 (1): 22-31. DOI: 10.22146/jml.18721. [Indonesian]

Kusmana C. 2017. Lesson learned from mangrove rehabilitation program in Indonesia. Jurnal Pengelolaan Sumberdaya Alam dan Lingkungan 7 (1): 89-97. DOI: 10.29244/jps1.7.1.89-97 [Indonesian]

Marlianingrum PR, Kusumastanto T, Adrianto L, Fahrudin A. 2019. Economic analysis of management option for sustainable mangrove ecosystem in Tangerang District, Banten Province, Indonesia. IOP Conf Ser: Earth Environ Sci 241 (1): 012026. DOI: 10.1088/17551315/241/1/012026.

Massiseng ANA, Tuwo A, Fachry ME, Bahar A. 2020. A dynamic simulation of mangrove ecotourism management at the Lantebung of Makassar City. IOP Conf Ser: Earth Environ Sci 584:012039. DOI: 10.1088/1755-1315/584/1/012039.

Mughofar A, Masykuri M, Setyono P. 2018. Zoning and vegetation composition of Cengkrong beach mangrove forest, Karanggandu Village, Trenggalek District, East Java Province. J Nat Resour Environ Manag 8 (1): 77-85. DOI: 10.29244/jpsl.8.1.77-85. [Indonesian]

Mursalim A, Nurdin N, La Nafie Y, Selamat B, Tresnati J, Tuwo A. 2020. Mangrove area and vegetation condition resulting from the planting of mangroves in the Wallacea Region, Bone Bay, South Sulawesi. IOP Conf Ser: Earth Environ Sci 473: 012055. DOI: 10.1088/17551315/473/1/012055.

Noor MT, Ully W. 2018. The Density and diversity of mangrove species relation to the sustainability of fisheries resources in Sidoarjo Regency. Intl J Fish Aquat Res 3 (2): 8-12.

Ramirez-Martínez GA, Castellanos-Galindo GA, Krumme U. 2016. Tidal and diel patterns in abundance and feeding of a marine-estuarinedependent fish from macrotidal mangrove creeks in the Tropical Eastern Pacific (Colombia). Estuar Coasts 39 (4): 1249-1261. DOI: 10.1007/s12237-016-0070-8.

Sari A, Tuwo A, Rani C, Saru A. 2020. Identification and composition of fish types in the Youtefa bay tourism area. IOP Conf Ser: Earth Environ Sci 564: 012023. DOI: 10.1088/1755-1315/564/1/012023.

Sawitri R, Bismark M, Karlina E. 2013. The mangrove ecosystem is a natural tourism object in the mangrove and Proboscis monkey conservation area in Tarakan City. Jurnal Penelitian Hutan dan Konservasi Alam 10 (3): 297-314. [Indonesian].

Schaduw JNW. 2018. Community structure and sustainable management of small islands mangrove ecosystems (The case on Nain Island, Minahasa Utara District, North Sulawesi Province). Jurnal Ilmu Lingkungan 16 (2): 120-129. DOI: 10.14710/jil.16.2.120-129. [Indonesian]

Sofian A, Harahab N, Marsoedi M. 2012. Conditions and direct benefits of mangrove forest ecosystem in Penunggul Village, Nguling District, Pasuruan Regency. El-Hayah 2 (2): 56-63. [Indonesian]

Suwarno J, Kartodiharjo H, Pramudya B, Rachman S. 2011. Development of sustainable management policies for the upper Ciliwung watershed, Bogor Regency. Jurnal Analisis Kebijakan Kehutanan 8 (2): 115-131. DOI: 10.20886/jakk.2011.8.2.115-131. [Indonesian] 
Tahang H, Amiluddin A, Amir F, Firman F. 2019. Economic valuation of mangrove ecosystem for sustainable use and management in Makassar. Biosci Res 16 (4): 3290-3297.

Thompson BS, Gillen J, Friess DA. 2018. Challenging the principles of ecotourism: insights from entrepreneurs on environmental and economic sustainability in Langkawi, Malaysia. J Sustain Tourism 26 (2): 257-276. DOI: 10.1080/09669582.2017.1343338.

Tresnati J, Aprilianto R, Tuwo A. 2020. Ecosystem and sustainable use of mangrove forests. In: Yogendra Singh Y (ed) Advances in Biologica Sciences and Biotechnology. Integrated Publications, New Delhi.

Tuwo A. 1997. Biodiversity and Marine Quality. Lontara 1997 Special Edition, Hasanuddin University, Makassar.
Tuwo A. 2011. Management of coastal and marine ecotourism: ecological, socio-economic, institutional and regional facilities approach. Indonesia, Brilian Internasional, Surabaya. [Indonesian]

Tuwo A, Tresnati J. 2020. Coral reef ecosystem. In: Singh Y (ed.) Advances in Biological Sciences and Biotechnology. Integrated Publications, New Delhi.

Vaslet A, Phillips DL, France C, Feller IC, Baldwin CC. 2012. The relative importance of mangroves and seagrass beds as feeding areas for resident and transient fishes among different mangrove habitats in Florida and Belize: evidence from dietary and stable-isotope analyses. J Exp Mar Biol Ecol 434: 81-93. DOI: 10.1016/j.jembe.2012.07.024

Yulianda F. 2019. Aquatic Ecotourism: A Concept of Suitability and Support for Marine Tourism and Freshwater Tourism. PT. Penerbit IPB Press, Bogor. [Indonesian] 